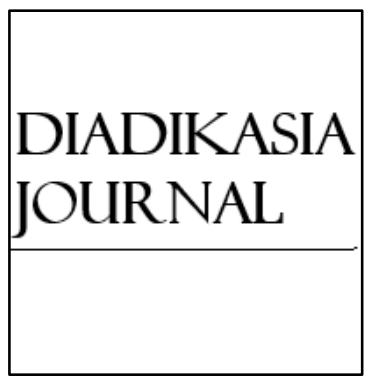

Diadikasia Journal

ISSN: $2721-9070$

Copyright $\odot 2020$ Diadikasia Organization

https://diadikasia.pubpub.org/

Volume 1(1): 11-23

DOI: $10.21428 / 8$ c841009.5494e7do

\title{
EXTRACURRICULAR MANAGEMENT PROGRAM TO IMPROVE STUDENTS 'NON-ACADEMIC ACHIEVEMENT ACTIVITIES IN MAN 3 CIREBON
}

\author{
Faizal Amir \\ faizalamir25@yahoo.com \\ IAIN Syekh Nurjati \\ Jl. Perjuangan, Cirebon, Indonesia 45131
}

\begin{abstract}
The development of extracurricular activities that are part of self-development at school is very important. In addition, many schools are known to the public because of their achievements in the academic field, yet there are not a few schools are chosen by the community because they have achievements in nonacademic fields, including through extracurricular activities. To be able to improve extracurricular achievements from students, management is needed as a part of education. MAN 3 Cirebon has a number of achievements in the field of extracurricular activities and won both district and provincial levels. Based on the background above, the authors conducted the study to reveal how the management of extracurricular programs to improve students' non-academic achievements in Cirebon 3 MAN. The evaluation process carried out is by determining the extent to which educational goals can be achieved through written test and practice which would be followed by an extracurricular team coordination meeting, where principals and parties involved in extracurricular activities to discuss developments and the obstacles faced during the implementation of extracurricular activities and solving the solution to be repaired in the next semester. The implication of this research is to increase the non-academic achievement of students through extracurricular programs, including training discipline, training students' talents, and schools are known to the wider community.
\end{abstract}

Keywords: Management, Extracurricular, Non-academic Achievements, Education.

\section{Introduction}

Regulation of the Minister of National Education of the Republic of Indonesia Number 39 the Year 2008 regarding student development mentions that student

11 | Diadikasia Journal. Vol. 1 No. 1, April 2020 
development aims to actualize students' potential in achieving superior performance according to their talents and interests and is carried out through extracurricular activities. The regulation of the minister of education intends to increase the talents and interests of students as human resources who have different and unique potentials, so as to be able to exploit the potential that exists in individuals. To develop the potential contained in each of these individuals, it takes activities that can support the potential and also maximum guidance. School, as one of the places that can be used to develop potential activities needed to be carried out outside of class hours, namely extracurricular activities.

Extracurricular are part of education in the form of learning activities carried out outside school hours. According to Percy E Burrup, he argues that: "variously referred to as extracurricular, co-curricular, our out-school activities they are perhaps best described as an extra class or simply student activities." This means various activities, such as Extracurricular activities or activities outside schools; these activities are better described as student activities (Soetopo Hendayat 1982). Meanwhile, according to Suryosubroto said that extracurricular activities are additional activities outside the program structure carried out outside regular school hours in order to enrich and broaden students' knowledge and abilities (B Suryosubroto 2002).

Extracurricular activities are carried out by the school and attended by students according to the talents and interests of each student. However, in reality, many students do not know their talents, so they only follow their friends in choosing extracurricular activities. Actually, students have a number of provisions or potential abilities of skills and personalities that are intact. As spirited and personable people, students themselves need to be positioned and guided and directed So that the potentials, talents, and abilities possessed can help the achievement of goals or competencies expected by students, especially increasing extracurricular performance.

The development of extracurricular activities that are part of self-development in schools becomes a very important thing. In addition to the many schools that are known to the community for academic achievements, not a few schools are chosen by the community because they have achievements in non-academic fields, including extracurricular activities. This does not rule out the possibility of making this extracurricular lesson sometimes the hallmark of a school. Extracurricular activities are an organizational environment that can influence students to carry out social interactions with others. Student participation in extracurricular activities will actually make a meaningful contribution for students to develop new interests, instill responsibilities as citizens through experiences and views of cooperation, and are accustomed to independent activities. (Teaching Team of IKIP Malang 1998) For can improve the extracurricular performance of students so as education needed management.

Management of extracurricular activities is the entire process planned and organized in an organized manner regarding school activities carried out outside the classroom and outside of class hours (curriculum) to grow and develop the potential of 
Human Resources (HR) owned by students, both related to the application of the knowledge they obtain as well as in a special sense to guide students in developing the potential and talent that exists in themselves through activities that are mandatory or optional. As learning and teaching activities outside the classroom. In management, there are at least three ways to achieve success in carrying out activities, namely: (a) Planning an extracurricular program. Planning is the basic process used to choose goals and determine the scope of their achievement. (Rusman 2017) Before, extracurricular teachers foster extracurricular activities in advance planning activities to be carried out. The design of this activity design is intended so that teachers have clear guidelines in training extracurricular activities. (b) The implementation of the extracurricular program is the activity of carrying out everything that has been planned to achieve the goal. In line with the opinion of George R. Terry, quoted by Rusman, stated that the actuating is an effort to move the group members in such a way that they wish and try (Rusman 2017).

Coaching extracurricular activities can vary from one school to another, the things that need to be known by extracurricular coaches are: (1) Activities must be able to increase the achievement of students who have cognitive, affective, and psychomotor perspectives. (2) Providing a place and channeling talents and interests so that students will get used to meaningful preoccupations. (3) The planning and preparation and guidance that have been carefully calculated so that the extracurricular program achieves its objectives. (4) Implementation of extracurricular activities by all or as students. (5) Evaluation of extracurricular programs. Evaluation is making consideration according to a set of agreed criteria and can be accounted for. (Fatah 2004) Whereas Muhaimin stated that evaluation is a systematic process in collecting, analyzing, and interpreting information to determine the level of success in implementing an educational institution program with certain criteria for decision-making needs. Or policy. The information and implementation of the evaluation will be compared with the targets set in the program (Muhaimin 2009).

After the program is finished, the coach needs to conduct an evaluation. This evaluation is intended to determine the benefits of the program for students and for schools. The results of this evaluation are useful for decision-makers to determine the need for an ongoing extracurricular program. Principals need to do an evaluation (evaluation) of the achievement of the goals and learning outcomes of their students. This action is useful to know the development of goals and results achieved by schools and is the data and information needed to plan and arrange further improvements. (Agung Iskandar 2013)

With the management in educational institutions, more specifically, the management of extracurricular programs, students are expected to excel in the extracurricular field according to their talents in the activities they are interested in.

In this study, the madrasa that will be examined is Madrasah Aliyah Negeri 3 Cirebon (MAN 3 Cirebon). MAN 3 Cirebon is a superior school located in the village of Mertapada Kulon within the scope of the Islamic Boarding School Buntet. MAN 3 Cirebon 
has a number of achievements in the extracurricular field and has become a champion at both the district and provincial levels. As one of the Islamic schools that strive to continue to progress and develop, MAN 3 Cirebon has planned and implemented extracurricular activities in the school, including in the religious fields (Qiro'ah and Hadroh), in the field of education (coaching Olympic maples), KIR (guidance for writing scientific papers, research, and scientific visits), sports (Basketball, Futsal, Athletics, Badminton, and table tennis) and yellow book studies. The following are the types of extracurricular activities at MAN 3 Cirebon, including:

Tabel. 1

\begin{tabular}{|c|c|c|}
\hline No & Nama Organisasi & Nama Pembina \\
\hline 1 & $\begin{array}{l}\text { Pasukan Pengibar Bendera } \\
\text { (PASKIBRA) }\end{array}$ & Ir. Kholilurrahman \\
\hline 2 & $\begin{array}{l}\text { Gerakan Pramuka Ambalan } \\
\text { KH.Abbas /Siti Khodijah }\end{array}$ & Indratno, S. Ag \\
\hline 3 & Palang Merah Remaja (PMR) & Drs. Dadang Sucipto \\
\hline 4 & Karya Ilmiah Remaja (KIR) & Juju Juhaeriyah, S. Pd \\
\hline 5 & Tim Kreatif Seni Alif & Hj. Uswatun Hasanah, M. Ag \\
\hline 6 & $\begin{array}{l}\text { Forum Kajian Kitab Kuning } \\
\text { (FK3) }\end{array}$ & Muhammad Lutfi, NZ, MA \\
\hline 7 & Olahraga & Indrawijaya, S. Pd \\
\hline 8 & Kompas & Drs. Dadang Scipto \\
\hline
\end{tabular}

The extracurricular activities schedule at MAN 3 Cirebon are as follows:

Tabel. 2

\begin{tabular}{cll}
\hline No & \multicolumn{1}{c}{ Nama Organisasi } & \multicolumn{1}{c}{ Jadwal Kegiatan } \\
\hline $\mathbf{1}$ & $\begin{array}{l}\text { Pasukan Pengibar Bendera } \\
\text { (PASKIBRA) }\end{array}$ & Kamis \& Minggu \\
$\mathbf{2}$ & $\begin{array}{l}\text { Gerakan Pramuka Ambalan } \\
\text { KH.Abbas /Siti Khodijah }\end{array}$ & Rabu \& Minggu \\
$\mathbf{3}$ & Palang Merah Remaja (PMR) & Rabu \& Minggu \\
$\mathbf{4}$ & Karya Ilmiah Remaja (KIR) & - \\
$\mathbf{5}$ & Tim Kreatif Seni Alif & Sabtu \& Minggu \\
$\mathbf{6}$ & Forum Kajian Kitab Kuning (FK3) & - \\
$\mathbf{7}$ & Olahraga & Rabu \& Minggu \\
$\mathbf{8}$ & Kompas & - \\
\hline
\end{tabular}

This extracurricular activity is carried out alternately after returning from school. So the extracurricular activities are handled by the coaches, student representatives, and assisted by members of the student council. So sometimes no one is watching the activity. However, based on the results of initial observations, it turned out that not all programs run smoothly. Like Kompas' extracurricular stops in the middle of the road or a temporary vacuum. This is due to miss-communication between the supervisor and the school. Finally, the school principal decided to extra complete Kompas to be vacated until next semester and get a replacement coach. 
From the observations of the author at MAN 3 Cirebon in September 2018, when viewed from the aspect of facilities and infrastructure already available such as science laboratories and computers, the field and others. But for the number of units, it still lacks and limited, so according to the researcher, it is also an obstacle to the implementation of activities. Whereas support from internal parties in the school, where the principal as a manager plays an active role in helping carry out existing extracurricular activities by providing good input and innovations. As for the evaluation of extracurricular activities, this has already been done. However, the extracurricular activities in MAN 3 Cirebon have not been fully improved, so the results have not been maximized. From these problems, the researchers are interested in conducting research on the management of extracurricular programs to improve the non-academic achievements of students in MAN 3 Cirebon and how the implications of the extracurricular activities are.

\section{Methods}

This research approach itself uses a qualitative approach, namely research that intends to understand the phenomena about what is experienced by research subjects, for example, behavior, perception, motivation, action, etc., holistically (Lexy J. Moeleong 2007). Researchers in qualitative research is very involved in the process of collecting data, or in other words, the instruments in qualitative research are the researchers themselves. This is reinforced by the opinion of Miles, the presence of researchers in the field in qualitative researchers is absolute because researchers act as research instruments once data collectors. The advantage gained from the presence of researchers as instruments is the subject is more responsive to the presence of researchers, researchers can adjust to the research setting. Decisions related to research can be taken quickly and directed, as well as information can be obtained through the attitudes and ways of informants in providing information. (Albi algianto \& JohanSetiawan 2018)

Data collection techniques are important steps in research so that they require appropriate data collection techniques to produce the appropriate data. According to Sugiyono, data collection techniques can be done by Observation (Observation), Interview (Interview), documentation, and a combination of the four. (Firdaus \& Fakhry Zamzam 2018). The researcher observes the role of being, while the researcher conducts a balanced approach between participation and observation at the research location where the researcher interacts with the informant and observes. For example, on the focus of the implementation of extracurricular activities in MAN 3 Cirebon, the researcher is in the classroom while interviewing the supervisor and observing the implementation of extracurricular activities in the school closely.

Passive participation can be in the form of researchers making observations without interacting with informants. For example, researchers made observations about the teaching and learning process in art extracurricular activities in tenth grade MAN 3 
Cirebon. Researchers make observations without participation in these activities, while full observation cannot be done by researchers because researchers are not included as members of the organization in each of these schools. In this study, researchers used structured and unstructured interviews. These researchers do by considering the situation and condition of the interview as well as the need for information that can develop at any time.

This method the author uses to obtain data on management that is applied in realizing extracurricular activities to improve the non-academic achievement of students, which includes planning, implementation, and evaluation. As well as the factors that support and inhibit the actualization of extracurricular activities from increasing nonacademic achievement of students in MAN 3 Cirebon. Furthermore, it will be known the impact felt by students with the existence of several extracurricular programs, the impacts faced by schools after carrying out extracurricular activities, and the impacts felt by stakeholders.

The study of documents in qualitative research is a complement to the use of observation and interview methods. Documentation study is collecting documents and data needed for research problems and then examined intensively so that it can support and increase the trust and proof of an event. The results of observations or interviews will be more credible/trustworthy if supported by documents related to the research focus. In research on Extracurricular Management to Improve Non-Academic Achievement of this Student, researchers will gather documents about various activities and momentum or school programs related to the research focus.

Analysis of the data in this study, researchers used interactive analysis containing four interrelated components, namely: data collection, data reduction, data exposure, withdrawal, and submission of conclusions. (Miles 1992) The steps in the analysis of the data are as follows:

(1) Data collection stage: At this stage, the researcher collects data relating to the following matters: Extracurricular management developed at MAN 3 Cirebon, including the content standards, processes and assessments, methods used, and media in extracurricular implementation and non-performance - academics achieved by students.

(2) Data Reduction. This process is the process of selecting, focusing on simplifying, abstracting, and transforming data or rough data resulting from field notes. Simplification can be done by making a summary and developing a coding system (coding) in order to facilitate in restating data that has been obtained. Data that need to be simplified is data obtained at the study site regarding extracurricular management to improve the non-academic achievements of students at MAN 3 Cirebon. This data, for example, data about the implementation of character education programs carried out in schools. Then the data then poured out in a complete or detailed description or report. (Muri Yusuf 2017). 
(3) Presentation of the data. The presentation of data in this study is also intended to find meaning from the data that has been obtained, then arranged systematically from a complex form of information to be simple and selective and easy to understand its meaning. The data obtained by researchers at MAN 3 Cirebon are then explained and understood the purpose of the data collected (Muh Fitrah \& Luthfiyah 2017).

(4) Conclusions (verification). The last activity in the data analysis is the conclusion (verification). At this stage, it is a process where the researcher is able to describe extracurricular management conducted in MAN 3 Cirebon and the events that occur during the research process in the field.

To gain trust in the results of the study, researchers used a technique proposed by Hengki Wijaya, namely: (1) Triangulation of Sources (researchers will check data from a source with other different sources). (Hengki Wijaya 2018) For example, data about the activities of the principal, which has been done through student office or other management at MAN 3 Cirebon Then the researcher asked again with other parties, such as teachers/staff, OSIS directly to find out whether there was a match of information or not. (2) Technical Translation: (checking the data to the source the same with different techniques) (Hengki Wijaya 2018)

For example, researchers want to reveal data about students' academic achievements, researchers will interview the curriculum, then proven with documents and also strengthened with the results of observations of researchers. (3) Triangulation Time time also often affects the credibility of the data. Data collected by interview techniques in the morning when the interviewees are still fresh, have not been many problems, will provide more valid data, so it is more credible. For this reason, in order to test the credibility of the data, it can be done by checking with interviews, observations, or other techniques in different times or situations. If the test results produce different data, then it is done repeatedly so that data certainty is found. (Hengki Wijaya 2018)

\section{Discussion}

Observing and analyzing the results of previous in-depth observations and interviews with informants who were accompanied by documentation studies and indepth observations, a general description of the findings and research findings relating to extracurricular management was presented to improve the non-academic achievements of students at MAN 3 Cirebon, including (1) Planning extracurricular activities program to improve students' non-academic achievements. (2) Implementation of extracurricular activity programs to improve the non-academic achievement of students. (3) Evaluation of extracurricular activities program to improve the non-academic achievement of students at MAN 3 Cirebon. (4) Implications of extracurricular activity programs to improve the non-academic achievement of students at MAN 3 Cirebon. 
From these findings, the authors sought to conduct an analysis of research findings related to extracurricular management to improve the non-academic achievements of students at MAN 3 Cirebon. This analyst is carried out by looking at the facts and findings of the field as described in the research findings and comparing them with existing concepts or theories in extracurricular management and non-academic achievement of students. After that, the writer will focus the discussion in accordance with the next problem of this research, namely extracurricular management, to improve the nonacademic achievements of students in MAN 3 Cirebon and the implications of the formation of extracurricular activities.

\section{A. Create Planning an Extracurricular Activities Program to Improve the Non-academic Achievements of Students at MAN 3 Cirebon.}

The results obtained in the field prove that MAN 3 Cirebon in carrying out extracurricular activities in madrasas has implemented functions in management, which includes planning, implementation, and evaluation. Although the implementation of functions as a whole has not been implemented properly. In the extracurricular function itself is as a means of support for the learning process carried out in schools that is useful for applying the theories and practices that have been obtained as a tangible result of the learning process. Oriented from this function, the existence of extracurricular activities as a form of accommodation for students' potential development processes (affective, cognitive, and psychomotor) will be able to accelerate the achievement of national education goals. This can be achieved if the concept of an activity can be formulated selectively so that it will be more easily understood by students, which in turn is expected to foster awareness in students that the activity is a series of teaching and learning processes that have been followed so far.

So that planning in extracurricular activities at MAN 3 Cirebon has been going well. This is proven by its activities in accordance with the specified references and objectives. These include a description of activities, targets, targets, time, the person in charge up to the source of funds. Planning in extracurricular activities at MAN 3 Cirebon will form activities aimed at making it easier for students to hone their interests and talents according to their respective fields of expertise. This is also a new innovation carried out by MAN 3 Cirebon. Integrate and classify extracurricular activities according to their categories or fields. And the results to be achieved by students after attending extracurricular lessons are usually students who are active in extracurricular activities will be skilled in organizing, managing, solving problems according to the extracurricular characteristics they are involved in.

Improving non-academic achievements is a priority program also planned by MAN 3 Cirebon. This is proven by a series of achievements in various competitions. In organizing extracurricular activities at MAN 3 Cirebon, proper management has been implemented in managing extracurricular program activities. The stages that were passed in the planning of the extracurricular program at MAN 3 Cirebon were: first, the work meeting 
at the beginning of the next year was followed up by the results of the meeting. Follow up was discussed internally by the coordination between the principal and students. Next, students coordinate with extracurricular coaches to discuss programs or strategies that will be implemented during the coming year. In the extracurricular planning stage, it is necessary to apply the method, the selection of the method is usually adjusted to the material to be taught because there may be suitable material given by discussion, but it is not effective if given by lecturing, or it can also be by combining both in one activity.

It can be concluded that the existence of the preparation of the work program as a clear frame of reference in each form of activity is expected to be able to eliminate any discrepancies between the objectives of the activity and its implementation in the field. The terms of reference referred to in this matter are in the form of plans regarding the implementation of extracurricular activities.

\section{B. Implementation of Extracurricular Activities Program to Improve Non-academic Achievements of Students at MAN 3 Cirebon}

Extracurricular activities carried out at MAN 3 Cirebon have been going well. Organized and in accordance with a predetermined schedule. Although sometimes there are a few obstacles in its implementation, it does not interfere with ongoing activities. The implementation of the MAN 3 Cirebon program includes the main tasks; the supervisor also has additional tasks, namely:

(1) Pre-surveying, the purpose is that if an activity is carried out outside the school environment, the pembina first make observations to the place to find out exactly whether or not the location is visited and can plan security aspects for students.

(2) Holding presentations for each exercise.

(3) Receiving special money, for example, savings, dues, book purchases, and so on.

(4) Provide an assessment of student presentations each semester, which is then included in the reported value.

(5) The general task is to deliver to the destination if the activity is carried out outside the school environment, such as competitions, performances, and travel.

Students at MAN 3 Cirebon are fostered in a variety of extracurricular activities on an ongoing and ongoing basis so that they have capable abilities and skills. After that, a student is selected by the supervisor and sent to participate in various competitions representing the school. In the management of Islamic education, so that the contents of the directions given to that given direction can be carried out properly, a director must at least pay attention to the following principles, namely: Exemplary, consistency, openness, tenderness, and policy. The contents of directives in the form of commands, prohibitions, and guidance should not be burdensome and beyond the capacity of the recipient's directives, because if that happens then do not expect the contents of the briefing to be carried out properly by the recipient's directives. 


\section{Evaluation of Extracurricular Activities Program to Improve the Non-academic Achievement of Students at MAN 3 Cirebon.}

Evaluation is a planned process and action to gather information about progress, growth, and development (students) towards goals (education), so that assessment can be compiled that can be used as a basis for making decisions. Thus the evaluation is not just assessing an activity spontaneously and incidental but is an activity to assess something that is planned, systematic, and based on clear objectives. So with the evaluation obtained information and conclusions about the success of an activity, and then we can determine alternatives and decisions for the next action.

Assessment or what is often referred to as evaluation is a function and principle of management to find out whether an organization's program reaches its goals or not. The process is based on data and facts. Without both, the assessment will not be valid and reliable so that it will plunge an individual or group of organizations to ruin. Meanwhile, according to Oteng Sutisna, assessment as a set of activities that can determine whether or not the programs or activities of the organization that is being carried out to achieve the goals that have been determined. Quoting Pudji Muljono's writing, evaluation is what difference is there with a certain standard, which is to find out whether there is a difference or not. Evaluation is the process of determining the extent to which educational goals can be achieved.

So the evaluation carried out in MAN 3 Cirebon is carried out by written test and practice will be followed by an extracurricular team coordination meeting, where the principal and parties involved in extracurricular activities such as student and curriculum office and extracurricular coaches discuss developments and obstacles encountered during the implementation of the activity extracurricular and solve the solution. To be repaired in the next semester.

\section{Implications of Extracurricular Activities Program to Increase the Non-academic Achievement of Students at MAN 3 Cirebon}

Based on the results of studies that researchers have conducted on the results of interviews and observations and documentation studies, the implications of increasing non-academic achievement of students through extracurricular programs include 1) training discipline and training student talent, 2) Schools are known to the wider community. This is in accordance with the objectives of the extracurricular activities listed in Permendiknas No. 39 of 2008, namely:

(1) Developing the potential of students in an optimal and integrated manner which includes talent, interest, and creativity,

(2) (2) Strengthening student personality to realize school resilience as an educational environment so as to avoid negative business and influence and conflicting with educational goals, 
(3) (3) Actualizing students' potential in achieving superior achievements according to their talents and interests,

(4) (4) Preparing students to become noble, democratic citizens who respect human rights in order to realize civil society. Said Allah QS Al Expect verse 11:

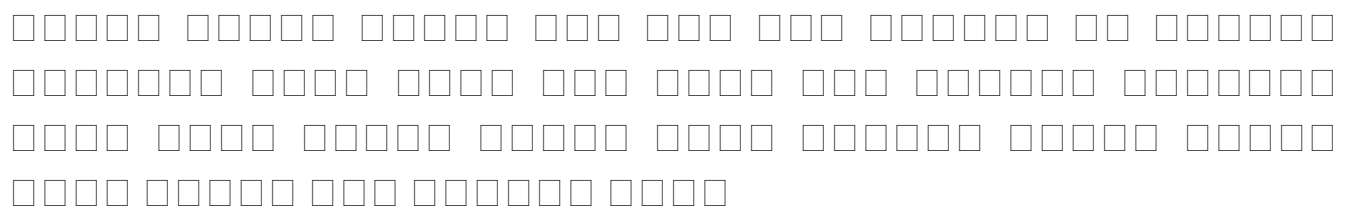

It means: "O you who believe if it is said to you:" Be roomy in the majlis, "then surely Allah will give you relief. And if it says: "Stand ye up," then stand up, Allah will exalt those who believe among you and those who are given some degree of knowledge. And Allah knows best what you do."

The above verse explains the position of the knowledgeable person, because of his intelligence and achievements so that he gets a high degree in the sight of Allah.

\section{Conclusion}

The planning implemented at MAN 3 Cirebon will form extracurricular activities aimed at making it easier for students to hone their interests and talents according to their respective fields of expertise. In its implementation, the supervisor has the general task of fostering MAN 3 Cirebon students in various extracurricular activities continuously and continuously so that they have capable abilities and skills. After that, a student is selected by the coach and sent to participate in various competitions representing the school and deliver to their destination if the activity is carried out outside the school environment, such as competitions, performances, and trips.

Evaluation is a planned process and action to gather information about progress, growth, and development (students) towards goals (education), so that assessment can be compiled that can be used as a basis for making decisions. Thus the evaluation is not just assessing an activity spontaneously and incidental but is an activity to assess something that is planned, systematic, and based on clear objectives. So with the evaluation obtained information and conclusions about the success of an activity, and then we can determine alternatives and decisions for the next action. So the process of determining the extent to which educational goals can be achieved through a written and practical test process will be followed by an extracurricular team coordination meeting, where the principal and parties involved in extracurricular activities such as student and curriculum time and extracurricular coaches discuss developments and obstacles encountered during the implementation of extracurricular activities and solving solutions. To be repaired in the next semester.

Based on the results of studies that researchers have conducted on the results of interviews and observations and documentation studies, the implications of increasing 
non-academic achievement of students through extracurricular programs include training discipline, training students' talents, and schools known to the wider community.

\section{References}

Ali, N. (2019). Integrative curriculum of religion and science at special pesantren for university students. Ulul Albab, 20(1), 95.

Apipudin, A. (2018). The Pesantren's Model of Resistance and Transformation in The Dynamics of Social Change in Indonesia. International Review of Humanities Studies, 1(1).

Celuch, K., Bačić, D., Chen, M. W., Maier-Lytle, J., \& Smothers, J. (2018). The Potential of Student Co-Creation in Extracurricular Experiences. Marketing Education Review, 28(3), 230-243.

Claudia, C. (2014). The role of extracurricular activities and their impact on learning process. THE ANNALS OF THE UNIVERSITY OF ORADEA, 1117.

Dewi, E. W., Drajati, N. A., \& Yunus, M. M. (2019). Exploring Intonations in Sesame Street's Puppet Shows: A Phonological Perspective. Issues in Language Studies, 8(2), 32-47.

Fattah, N. (2019). Landasan manajemen pendidikan.

Habibi, H. (2018). Protecting National Identity Based On The Value Of Nation Local Wisdom. International Journal of Malay-Nusantara Studies, 1(2), 24-40.

Habibi, H. (2016). Peran Ki Dalang Basari (1950-2003) dalam Perkembangan Islam di Gegesik Cirebon. Jurnal Tamaddun: Jurnal Sejarah dan Kebudayaan Islam, 1(2).

Hasanah, A., Gustini, N., \& Rohaniawati, D. (2016). Cultivating character education based on sundanese culture local wisdom. Jurnal Pendidikan Islam, 2(2), 231-253.

Han, A., \& Kwon, K. (2018). Students' Perception of Extracurricular Activities: a Case Study. Journal of Advances in Education Research, 3(3), 131-141.

Husniyah, N. I. (2015). Religious Culture Dalam Pengembangan Kurikulum PAI. AKADEMIKA, 9.

Ilaria, V., \& Emanuela, R. (2019). Elements and methods of organization, design and management of extracurricular sports activities. Journal of Physical Education and Sport, 19, 1767-1772.

Kurniawan, A. (2019). Optimization of Humanistic Education in the Integrated Islamic Primary School. Al Ibtida: Jurnal Pendidikan Guru MI, 6(1), 37-48.

Lexy, M. (2002). Metode Penelitian Kualitatif, PT. Remaja Rosdakarya, Bandung.

Manzilati, A. (2017). Metodologi Penelitian Kualitatif: Paradigma, Metode, dan Aplikasi. Universitas Brawijaya Press.

Miles, M. B., \& Huberman, A. M. (1992). Analisis data kualitatif.

Rifai, N. (2006). The Emergence of Elite Islamic Schools in Contemporary Indonesia: A Case Study of Al Azhar Islamic School (Doctoral dissertation, McGill University).

Shaffer, M. L. (2019). Impacting Student Motivation: Reasons for Not Eliminating Extracurricular Activities. Journal of Physical Education, Recreation \& Dance, 90(7), 8-14.

Silliker, S. A., \& Quirk, J. T. (1997). The effect of extracurricular activity participation on the academic performance of male and female high school students. The School Counselor, 44(4), 288-293.

Sudjana, N. (1995). Penilaian hasil proses belajar mengajar.

Sulfemi, W. B. (2019). Manajemen Kurikulum di Sekolah.

Soetopo, H., \& Soemanto, W. (1982). Pengantar Operasional Administrasi Pendidikan. Surabaya: Usaha Nasional.

Syafril, M. P., \& Zen, Z. (2019). Dasar-Dasar Ilmu Pendidikan. Prenada Media.

Tulung, J. (2017). Beyond Indoctrination: Study Of The Juxtaposition On Madrasah Capacity In East Jakarta And Christian School In North Sulawesi.

Usman, N. (2019). Strategi Kepala Sekolah dalam Meningkatkan Kompetensi Guru pada SMP Negeri 16 Kota Banda Aceh. Jurnal Administrasi Pendidikan: Program Pascasarjana Unsyiah, 7(1).

Yusuf, A. M. (2016). Metode penelitian kuantitatif, kualitatif \& penelitian gabungan. Prenada Media. 
Faizal Amir: Extracurricular Management Program to Improve Students 'Non-Academic Achievement Activities in MAN 3 Cirebon

Wijaya, H. (2018). Analisis Data Kualitatif Ilmu Pendidikan Teologi. Sekolah Tinggi Theologia Jaffray.

Cite: Amir, F. (2020). Extracurricular Management Program to Improve Students 'Non-Academic Achievement Activities in MAN 3 Cirebon. Diadikasia Journal, 1(1), 11-23. https://doi.org/10.21428/8c841009.5494e7do 